\title{
Improvement of Soil Fertility and Rice Productivity with Use of Coal Derived Humic Acid and Mineral Fertilization under Inceptisol of Varanasi, India
}

\author{
Dileep Kumar ${ }^{182}$ A. P. Singh ${ }^{1}$ and V. S. Meena ${ }^{3}$
}

\author{
${ }^{1}$ Dept. of Soil Science and Agricultural Chemistry, Institute of Agricultural Sciences, BHU, Varanasi, Uttar Pradesh (221 005), India \\ ${ }^{2}$ Micronutrient Research Project, Anand Agricultural University, Anand, Gujarat (388 110), India \\ ${ }^{3}$ ICAR-Vivekananda Institute of Hill Agriculture, Almora, Uttarakhand (263 601) India
}

\section{Corresponding Author}

Dileep Kumar

e-mail: dileepdixit.bhu@gmail.com

\author{
Article History \\ Article ID: AR1826 \\ Received in $21^{\text {st }}$ July, 2017 \\ Received in revised form $18^{\text {th }}$ September, 2017 \\ Accepted in final form $5^{\text {th }}$ October, 2017
}

\begin{abstract}
Use of organic and inorganic fertilizers in balanced and integrated manner may enhance the accumulation of soil organic matter and improves soil physical properties. A two year replicated pot experiment was conducted to assess the influence of coal derived potassium humate $(\mathrm{PH})$ and mineral fertilizers. The experiment followed a completely randomized $2 \times 3 \times 2 \times 3$ factorial design comprising two fertility levels $(75$ and $100 \% \mathrm{NPK}$ ), three doses of PH (0;5.0; and $10.0 \mathrm{mg} \mathrm{kg}^{-1}$ ), two doses of zinc sulphate (0; and $12.5 \mathrm{mg} \mathrm{kg}^{-1}$ ). Results showed significant enhancement in rice grain yield as well as availability of nutrients with sole and combined application of $10 \mathrm{mg} \mathrm{kg}^{-1} \mathrm{PH}$ with $100 \% \mathrm{NPK}$ and $12.5 \mathrm{mg} \mathrm{kg}^{-1}$ zinc sulphate as compared to 75 and $100 \%$ of NPK alone. Meanwhile, use of $\mathrm{PH}_{10}$ showed $\sim 35 \%$ higher grain yield compared without $\mathrm{PH}_{0}$ application, it was $\sim 19 \%$ higher as compared to $\mathrm{PH}_{5}$. Significant interaction effect of different levels of PH with NPK and zinc was observed in grain yield. Application of $100 \%$ NPK with $10 \mathrm{mg} \mathrm{kg}^{-1} \mathrm{PH}$ significantly enhances nutrient availability as compared to control treatment after rice harvest. These results suggested that the used of $\mathrm{PH}$ and mineral fertilization in integrated manner enhance the crop productivity as well as soil fertility of rice system in the alluvial soil under Indo-Gangetic Plain of India.
\end{abstract}

Keywords: Potassium humate; mineral fertilization; rice productivity; soil sustainability

\section{Introduction}

Nowadays, rising cost of chemical and mineral fertilizers and enhance the illness effects arising in soil-water-plant system from their imbalanced application has made the use of organic manures imperative for cutting down the quantity of chemical fertilizers without sacrificing the crop and soil sustainability. Due to the imbalanced fertilization in Indian agriculture from few decades it is noticed that majority of the Indian soils have become deficient in nitrogen $(N)$, low to medium in phosphorous (P) and over time, potassium (K) deficiency has also become widespread because of continuous removal of nutrients from the soil by the crops over a period. The chronic uses of industrial NPK fertilization have damaged the properties of soil (Lim et al., 2015), and caused many serious agro-ecological problems (Singh and Verma, 2007). The reinstallation of soil sustainability is mostly dependent on adequate presence of soil organic matter (SOM) in the soilplant system. However, in view of the limited availability of organic resources and their fast decomposition under tropical conditions, there is a need to adopt new strategies involving unconventional sources of such organic inputs which are resistant to decomposition (Lim et al., 2015).

One of the novel organic material is $\mathrm{PH}$ such material which has been reported (Turgay et al., 2011; Kumar et al., 2013) to have potential to improve soil and environmental sustainability (Ibrahim and Ramadan, 2015). It is a concentrated form of humus in the naturally occurring ignites which is the brown coal that accompanies coal deposits. This is an eco-friendly novel material which could sustain soil and crop productivity. The humic acid (HA) consists of conglomerate chemically reactive functional groups (carboxyls, phenolic, and alcoholic hydroxyls) as well as $\mathrm{pH}$ dependent properties (AlvarezPuebla et al., 2005). It is a low cost natural supplement for improving cycling and availability of nutrients, soil health and crop growth, the improving in soil fertility, quality and crop productivity in response tolignite coal-derived humic acid (Arjumend et al., 2015).

This novel organic materials applied to soil can support buildup of SOM and nutrient status of the soil and these soils have usually a more active microbial population (Vallini et al., 
1993). This in term improves soil sustainability as a result of increased SOM content and concurrent decreases in soil borne diseases. Humic substances also influence indirectly the rhizospheric microorganisms through their cation exchange capacity (CEC). Therefore, essential cations are either made available such as iron ( $\mathrm{Fe}$ ) or toxic concentrations of copper (Cu) are chelated and allowing microbial growth (Charest et al. 2004). Nowadays, humic substances were combined used with helpful microorganisms as plant growth promoter (PGP) or biological control agents to enhance crop sustainability (Naidu et al., 2013; Olivares et al., 2015).

India has the largest area under rice cultivation ( $43.8 \mathrm{M}$ ha) and occupies second position in production ( $\sim 104.8 \mathrm{Mt})$ next to China among rice growing countries of the world (Anonymous, 2015). The relatively poor productivity of rice in India is also linked with low organic carbon content of rice growing soils. Still very little research work has been carried out in the direction to use of humic acid by cereals crops.

\section{Materials and Methods}

A two year replicated pot experiment was conducted in the net house of the Department of Soil Science and Agricultural Chemistry, Institute of Agricultural Sciences, Banaras Hindu University, Varanasi, India, located between $25.14^{\circ}$ and $25.23^{\circ} \mathrm{N}$ latitude and $82.56^{\circ}$ and $83.03^{\circ} \mathrm{E}$. The soil was an alluvial representing an Inceptisol (Typic Ustochrept). For conducting the pot experiment, the bulk surface soil $(\sim 15 \mathrm{~cm})$ was collected from the Agricultural Research Farm, Institute of Agricultural Sciences, Banaras Hindu University, Varanasi, India. The experimental soil had sandy loam texture, $1.43 \mathrm{Mg}$ $\mathrm{m}^{-3}$ bulk density, $2.62 \mathrm{Mg} \mathrm{m}^{-3}$ particle density, $7.9 \mathrm{pH}, 0.211$ dS m-1 EC, $4.3 \mathrm{~g} \mathrm{~kg}^{-1}$ organic carbon, $185 \mathrm{~kg} \mathrm{ha}^{-1}$ available nitrogen, $17 \mathrm{~kg} \mathrm{ha}^{-1}$ available phosphorus, $199 \mathrm{~kg} \mathrm{ha}^{-1}$ available potassium, and $10.24 \mathrm{mg} \mathrm{kg}^{-1}$ available sulphur. The $\mathrm{PH}$ used for experimentation, obtained from Gangeya Agro India Ltd. Lucknow, India. Product was manufactured by Pranav Bio. Tech, Mumbai, India. It contained $70 \%$ humic acid, $49.5 \%$ total carbon and $\sim 10 \%$ potassium with $\sim 95 \%$ solubility. The collected bulk soil sample was air-dried under shade and crushed with a wooden roller and passed through sieve having openings of $2 \mathrm{~mm}$ diameter and $\sim 8 \mathrm{~kg}$ of soil filled in the each polythene lined pot. Soil in each pot was puddled manually with the help of wooden rod and five seedlings of rice (variety Malviya-36) transplanted. After establishment, four plants were maintained. The experiment followed a completely randomized $2 \times 3 \times 2 \times 3$ factorial design comprising two fertility levels ( 75 and $100 \%$ NPK), three doses of PH (0; 5.0; and $\left.10.0 \mathrm{mg} \mathrm{kg}^{-1}\right)$, two doses of zinc sulphate (0; and $\left.12.5 \mathrm{mg} \mathrm{kg}^{-1}\right)$, with three replicate, hence total 36 pots were arranged. Treatments of recommended dose of fertilizers (60 $\mathrm{mg} \mathrm{kg}{ }^{-1} \mathrm{~N}, 30 \mathrm{mg} \mathrm{kg}^{-1} \mathrm{P}$ and $\left.30 \mathrm{mg} \mathrm{kg}^{-1} \mathrm{~K}\right) \mathrm{Zn}$ and $\mathrm{PH}$ in $\mathrm{mg} \mathrm{kg}^{-1}$ soil using stock solutions of urea, $\mathrm{KH}_{2} \mathrm{PO}_{4}, \mathrm{KCl}$, zinc sulphate and $\mathrm{PH}$, respectively was applied to all the pots. The pots were irrigated and $\sim 2 \mathrm{~cm}$ of standing water was maintained by daily addition of water. The initial physico-chemical properties of experimental soil are given in Table 1.

The samples were collected after harvesting of rice crop and analyzed for $\mathrm{pH}, \mathrm{EC}$, as per the procedure described by Jackson (1973). Cation exchange capacity (CEC) was determined by leaching the soil with $1 \mathrm{~N} \mathrm{NH}_{4} \mathrm{OAc}$ and subsequently displacing the adsorbed $\mathrm{NH}^{4+}$ following the methods of Schollenberger and Simon (1945) and bulk density by (Richard 1954). The soil organic carbon was determined by wet digestion method of Walkley and Black (1934) and the available nitrogen was estimated by Subbaiah and Asija (1956). The available phosphorus in the soil was extracted by employing Olsen extractant $\left(0.5 \mathrm{M} \mathrm{NaHCO}_{3}, \mathrm{pH} 8.5\right)$ as described by Olsen et al. (1954) and the exchangeable potassium was extracted by using neutral normal ammonium acetate $(\mathrm{pH} \mathrm{8.5)}$ and the content was determined by aspirating the extract into flame photometer (Jackson, 1973). The available S was extracted with $0.15 \%$ calcium chloride solution and estimated as described by Chesnin and Yien (1951) and the content of DTPA extractable zinc were estimated using 1:2 soil to extractant ratio (Lindsay and Norvell 1978) by atomic absorption spectrophotometer manufactured by Unicam Atomic Absorption Ltd., York street Cambridge.

The statistical analysis of the data was done by the analysis

\begin{tabular}{|c|c|c|c|c|c|c|c|c|c|c|c|c|}
\hline \multirow{3}{*}{$\begin{array}{l}\text { Treat- } \\
\text { ments }\end{array}$} & \multicolumn{12}{|c|}{ Grain yield $\left(\mathrm{g} \mathrm{pot}^{-1}\right)$} \\
\hline & \multicolumn{2}{|c|}{2009} & \multirow[t]{2}{*}{ Mean } & \multicolumn{2}{|c|}{2010} & \multirow[t]{2}{*}{ Mean } & \multicolumn{2}{|c|}{2009} & \multirow[t]{2}{*}{ Mean } & \multicolumn{2}{|c|}{2010} & \multirow[t]{2}{*}{ Mean } \\
\hline & $\mathrm{NPK}_{75 \%}$ & $\mathrm{NPK}_{100 \%}$ & & $\mathrm{NPK}_{75 \%}$ & $\mathrm{NPK}_{100 \%}$ & & $\mathrm{Zn}_{0}$ & $\mathrm{Zn}_{12.5}$ & & $\mathrm{Zn}_{0}$ & $\mathrm{Zn}_{12.5}$ & \\
\hline $\mathrm{PH}_{0}$ & 30.29 & 36.61 & 33.45 & 30.51 & 36.76 & 33.63 & 32.44 & 34.45 & 33.45 & 32.65 & 34.62 & 33.63 \\
\hline $\mathrm{PH}_{5}$ & 34.59 & 40.23 & 37.41 & 35.36 & 42.40 & 38.88 & 36.38 & 38.44 & 37.41 & 37.64 & 40.12 & 38.88 \\
\hline $\mathrm{PH}_{10}$ & 42.94 & 45.68 & 44.31 & 45.06 & 47.23 & 46.14 & 41.76 & 46.85 & 44.31 & 43.07 & 49.22 & 46.14 \\
\hline Mean & 35.94 & 40.84 & & 36.97 & 42.13 & & 36.86 & 39.91 & & 37.78 & 41.32 & \\
\hline \multirow[t]{2}{*}{$\begin{array}{l}\text { NPKx } \\
\text { PH }\end{array}$} & SEm \pm & $\begin{array}{c}\text { LSD } \\
(p=0.05)\end{array}$ & & SEm \pm & $\begin{array}{c}\text { LSD } \\
(p=0.05)\end{array}$ & $\begin{array}{l}\mathrm{PH} \times \\
\mathrm{Zn}\end{array}$ & SEm \pm & $\begin{array}{c}\text { LSD } \\
(p=0.05)\end{array}$ & & SEm \pm & $\begin{array}{c}\text { LSD } \\
(p=0.05)\end{array}$ & \\
\hline & 0.63 & 1.84 & & 0.65 & 1.90 & & 0.63 & 1.84 & & 0.65 & 1.90 & \\
\hline
\end{tabular}


of variance (ANOVA). The means were tested for significance at $p \leq 0.05$.

\section{Results and Discussion}

Data showed that PH treatments, significantly greatest mean grain yield was obtained from the treatment of $\mathrm{PH}_{10}(44.31$ $\mathrm{g} \mathrm{pot}^{-1}$ ) fallowed by $\mathrm{PH}_{5}\left(37.41 \mathrm{~g} \mathrm{pot}^{-1}\right)$, it was significantly superior compared to $\mathrm{PH}_{0}\left(33.45 \mathrm{~g} \mathrm{pot}^{-1}\right)$. Similar to from the first year, the greatest value was obtained by the treatment of $\mathrm{PH}_{10}$ fallowed by $\mathrm{PH}_{5}$ and the effects of combined treatments of $\mathrm{PH}$ with chemical fertilizers (PH×NPK) and $\mathrm{PH}$ with zinc sulphate $(\mathrm{PH} \times \mathrm{Zn})$ on grain yield were more apparent and gave greater values than treatment $\mathrm{NPK}_{75 \%}$ and $\mathrm{NPK}_{100 \%}$ alone (Table 1). The significantly highest grain yield in addition of $\mathrm{PH}$ in present study reveal that humic acid enhanced the availability of the plant nutrients and improved yield components and yield of rice crop. Application of $\mathrm{PH}$ along with micronutrients increased $\sim 30 \%$ yield of crops (Ibrahim and Ramadan, 2015; Suh et al. 2014; Canellas et al., 2015).

Results showed that the application of $10 \mathrm{mg} \mathrm{kg}^{-1} \mathrm{PH}$ significantly reduced $\mathrm{pH}$ of the soil as compared to $5 \mathrm{mg} \mathrm{kg}^{-1}$ $\mathrm{PH}$. It may be due to initially alkalinie in soil reaction being reduced due to submergence during rice cultivation (Shahid et al., 2012; Guo et al. 2010). As a consequence of the reduction of the $\mathrm{pH}$ of soil we found that EC of the soil was significantly higher in $\mathrm{PH}$ treated pots as well as with $\mathrm{NPK}_{100 \%}$ than $\mathrm{NPK}_{75 \%}$ in both the years (Table 2). This was may be due to release acid forming compounds from decomposing organic materials that reacted with the sparingly soluble salts which already present in the soil and either at least increased their solubility or converted them into soluble salts. The decrease in $\mathrm{pH}$ of the soil might have also enhanced the discharge of inorganic salts thereby increasing EC of the soil (Bai et al., 2010; Kutuk et al., 2000).

There was a steady increase in CEC with increased levels of potassium humate. The highest $\mathrm{CEC}$ was observed with $\mathrm{PH}_{10}$ followed by $\mathrm{PH}_{5}$ during the two years of experimentation. The lowest CEC was found where no $\mathrm{PH}$ was added $\mathrm{PH}_{0}$ (Table 2). The profound increase in $\mathrm{CEC}$ due to $\mathrm{PH}$ in the present study highlighted the beneficial effect of HA on CEC. The HA has been reported to contain functional groups, that form the source of negative charge which could have contributed towards the CEC of the soil. The lignite brown coal are alkaline, rich in carboxylic and phenolic groups, aromatic in nature and enhanced cation exchange capacity of soil (Ali et al., 2010).

Data showed that the significantly variation were observed

Table 2: Effect of potassium humate and chemical fertilizers on physicochemical properties of soil

\begin{tabular}{|c|c|c|c|c|c|c|c|c|c|c|c|c|}
\hline \multirow[t]{2}{*}{ Treatment } & \multicolumn{2}{|c|}{$\begin{array}{c}\mathrm{pH} \\
(1: 2.5)\end{array}$} & \multicolumn{2}{|c|}{$\begin{array}{c}E C \\
\left(\mathrm{dSm^{-1 }}\right)\end{array}$} & \multicolumn{2}{|c|}{$\begin{array}{l}\text { Organic car- } \\
\text { bon }\left(\mathrm{g} \mathrm{kg}^{-1}\right)\end{array}$} & \multicolumn{2}{|c|}{$\begin{array}{c}\text { CEC } \\
\left(\mathrm{C} \mathrm{mol}(p+) \mathrm{kg}^{-1}\right) \\
\end{array}$} & \multicolumn{2}{|c|}{$\begin{array}{l}\text { Bulk density } \\
\left(\mathrm{Mg} \mathrm{m}^{-3}\right)\end{array}$} & \multicolumn{2}{|c|}{$\begin{array}{c}\text { Water holding } \\
\text { capacity (\%) }\end{array}$} \\
\hline & 2009 & 2010 & 2009 & 2010 & 2009 & 2010 & 2009 & 2010 & 2009 & 2010 & 2009 & 2010 \\
\hline \multicolumn{13}{|c|}{ Factor I NPK (\%) } \\
\hline $\mathrm{NPK}_{75 \%}$ & 8.42 & 8.14 & 0.204 & 0.209 & 5.21 & 5.29 & 15.30 & 15.65 & 1.45 & 1.44 & 44.11 & 45.05 \\
\hline $\mathrm{NPK}_{100 \%}$ & 8.37 & 8.14 & 0.228 & 0.226 & 5.49 & 5.64 & 16.23 & 16.93 & 1.43 & 1.42 & 45.45 & 46.10 \\
\hline SEm \pm & 0.04 & 0.02 & 0.003 & 0.003 & 0.04 & 0.05 & 0.11 & 0.15 & 0.01 & 0.01 & 0.21 & 0.32 \\
\hline $\operatorname{LSD}(p=0.05)$ & 0.12 & 0.06 & 0.007 & 0.009 & 0.11 & 0.15 & 0.33 & 0.45 & 0.03 & 0.02 & 0.61 & 0.94 \\
\hline \multicolumn{13}{|c|}{ Factor II potassium humate $\left(\mathrm{mg} \mathrm{kg}^{-1}\right)$} \\
\hline $\mathrm{PH}_{0}$ & 8.42 & 8.22 & 0.194 & 0.201 & 5.09 & 5.12 & 14.20 & 14.40 & 1.46 & 1.45 & 43.14 & 43.89 \\
\hline $\mathrm{PH}_{5}$ & 8.41 & 8.10 & 0.223 & 0.218 & 5.29 & 5.38 & 15.66 & 16.03 & 1.44 & 1.43 & 45.05 & 45.83 \\
\hline $\mathrm{PH}_{10}$ & 8.35 & 8.10 & 0.233 & 0.233 & 5.67 & 5.89 & 17.42 & 18.45 & 1.42 & 1.40 & 46.16 & 47.00 \\
\hline SEm \pm & 0.05 & 0.02 & 0.003 & 0.004 & 0.05 & 0.06 & 0.14 & 0.19 & 0.01 & 0.01 & 0.25 & 0.40 \\
\hline $\operatorname{LSD}(p=0.05)$ & 0.14 & 0.07 & 0.009 & 0.011 & 0.14 & 0.18 & 0.40 & 0.55 & 0.04 & 0.02 & 0.75 & 1.15 \\
\hline \multicolumn{13}{|c|}{ Factor III Zinc sulphate $\left(\mathrm{mg} \mathrm{kg}^{-1}\right)$} \\
\hline $\mathrm{Zn}_{0}$ & 8.43 & 8.19 & 0.215 & 0.214 & 5.29 & 5.36 & 15.38 & 15.79 & 1.44 & 1.43 & 42.89 & 43.89 \\
\hline $\mathrm{Zn}_{12.5}$ & 8.36 & 8.09 & 0.217 & 0.220 & 5.41 & 5.57 & 16.15 & 16.79 & 1.44 & 1.43 & 46.68 & 47.26 \\
\hline SEm \pm & 0.04 & 0.02 & 0.003 & 0.003 & 0.04 & 0.05 & 0.11 & 0.15 & 0.01 & 0.01 & 0.21 & 0.32 \\
\hline $\operatorname{LSD}(p=0.05)$ & 0.12 & 0.06 & NS & NS & 0.11 & 0.15 & 0.33 & 0.45 & NS & NS & 0.61 & 0.94 \\
\hline \multicolumn{13}{|l|}{ Interaction } \\
\hline PH $\times N P K$ & & & & & $\mathrm{~s}$ & $\mathrm{~s}$ & NS & NS & NS & NS & NS & NS \\
\hline
\end{tabular}

NPK (60-30-30 mg kg-1 corresponding to 120,60 , and $60 \mathrm{~kg} \mathrm{ha}^{-1}$ of $\mathrm{N}_{1} \mathrm{P}_{2} \mathrm{O}_{5}$ and $\mathrm{K}_{2} \mathrm{O}$ respectively); $\mathrm{PH}$ : Potassium humate 
among the $\mathrm{PH}$ treatment and it was significantly lower bulk density (1.42 and $1.40 \mathrm{Mg} \mathrm{m}^{-1}$ ) with $\mathrm{PH}_{10}$ that received $10 \mathrm{mg}$ $\mathrm{kg}^{-1} \mathrm{PH}$ and the highest bulk density (1.46 and $1.45 \mathrm{Mg} \mathrm{m}^{-1}$ ) was observed in the pots that did not receive any $\mathrm{PH}_{0}$ during first and second year of experiment respectively (Table 2). The significant reduction in bulk density was also observed with application of $5 \mathrm{mg} \mathrm{kg}^{-1}$ of during both the years of experimentation (Huiet et al., 2012). The decrease in bulk density has been attributed to higher organic matter content of soil, better aggregation and increased root growth in fertilizer and organic treated plots (Sarwar et al., 2012; Bai et al., 2010; Kutuk et al., 2000).

Results showed that the WHC significantly higher was recorded (46.16 and 47.00\%) with having $10 \mathrm{mg} \mathrm{kg}^{-1} \mathrm{PH}$ which was significantly higher than $\mathrm{PH}_{0}$ during both the years (Table 2). The significant increase in WHC with the combination of organic sources and chemical fertilizers might be attributed to increased organic matter status of the soil and improved soil structure (Triplett et al., 1968; Sarwar et al., 2012).

Results showed that the application of $\mathrm{PH}$ significantly increased organic carbon (OC) in soil. The highest OC 5.67 and $5.89 \mathrm{~g} \mathrm{~kg}^{-1}(p<0.05)$ was observed under $\mathrm{PH}_{10}$ followed by $\mathrm{PH}_{5}\left(5.29\right.$ and $\left.5.38 \mathrm{~g} \mathrm{~kg}^{-1}\right)$ during both the years of experimentation (Table 2). The positive effect might be due to the high content of organic carbon in PH itself (Bhama et al., 2003).

Data showed that the treatment $\mathrm{PH}_{10}$ caused $17 \%$ increase in available $\mathrm{N}$ content in soil over $\mathrm{PH}_{0}$ during first year and $18 \%$ during second year. With combined application of $100 \%$ NPK with $10 \mathrm{mg} \mathrm{kg}^{-1} \mathrm{PH}$ recorded significantly higher available $\mathrm{N}$ in soil during both the years (Table 3 and 4). The increase in available $\mathrm{N}$ might be attributed to the enhanced microbial activities induced by humic acid (Masciandaro and Ceccanti 1999). Due to the application of $10 \mathrm{mg} \mathrm{kg}^{-1} \mathrm{PH}$ resulted in $25 \%$ increase in available $\mathrm{P}$ content in soil over $\mathrm{PH}_{0}$ during 2009 and 24\% during 2010 (Figure 1). The treatment $\mathrm{PH}_{10} \times \mathrm{NPK}_{100 \%}$ produced significantly greater available $\mathrm{P}$ over other treatments during both the years of experimentation (Table 3 and 4).

Meanwhile data showed that the $\mathrm{PH}_{10}$ recorded higher exchangeable $\mathrm{K}$ content in soil, causing an enhancement of $16 \%$ in 2009 and $18 \%$ in 2010 over $\mathrm{PH}_{0}$ (Figure 1). The interaction effect of PH with NPK was found to be significant (Table 4). The highest exchangeable $\mathrm{K}$ content was obtained from treatment $\mathrm{PH}_{10} \times \mathrm{NPK}_{100 \%}$ followed by $\mathrm{PH}_{0} \times \mathrm{NPK}_{75 \%}$ (Table 4). Significantly highest value of available sulphur content in

\begin{tabular}{|c|c|c|c|c|c|c|c|c|c|c|}
\hline \multirow[t]{2}{*}{ Treatment } & \multicolumn{2}{|c|}{$\begin{array}{l}\text { Nitrogen } \\
\left(\mathrm{mg} \mathrm{kg}^{-1}\right)\end{array}$} & \multicolumn{2}{|c|}{$\begin{array}{c}\text { Phosphorus } \\
\left(\mathrm{mg} \mathrm{kg}^{-1}\right)\end{array}$} & \multicolumn{2}{|c|}{$\begin{array}{c}\text { Potassium } \\
\left(\mathrm{mg} \mathrm{kg}^{-1}\right)\end{array}$} & \multicolumn{2}{|c|}{$\begin{array}{l}\text { Sulphur } \\
\left(\mathrm{mg} \mathrm{kg}^{-1}\right)\end{array}$} & \multicolumn{2}{|c|}{$\begin{array}{c}\text { Zinc } \\
\left(\mathrm{mg} \mathrm{kg}^{-1}\right)\end{array}$} \\
\hline & 2009 & 2010 & 2009 & 2010 & 2009 & 2010 & 2009 & 2010 & 2009 & 2010 \\
\hline \multicolumn{11}{|c|}{ Factor I NPK (\%) } \\
\hline $\mathrm{NPK}_{75 \%}$ & 108 & 110 & 11.03 & 11.98 & 125 & 130 & 9.98 & 11.02 & 0.59 & 0.63 \\
\hline $\mathrm{NPK}_{100 \%}$ & 118 & 119 & 11.60 & 12.73 & 137 & 140 & 10.68 & 11.87 & 0.88 & 0.92 \\
\hline SEm \pm & 0.80 & 0.81 & 0.08 & 0.09 & 0.62 & 0.64 & 0.10 & 0.11 & 0.01 & 0.01 \\
\hline $\operatorname{LSD}(p=0.05)$ & 2.34 & 2.37 & 0.23 & 0.26 & 1.80 & 1.87 & 0.28 & 0.32 & 0.026 & 0.028 \\
\hline \multicolumn{11}{|c|}{ Factor II Potassium humate $\left(\mathrm{mg} \mathrm{kg}^{-1}\right)$} \\
\hline $\mathrm{PH}_{0}$ & 104 & 105 & 10.10 & 11.05 & 121 & 124 & 9.88 & 10.93 & 0.68 & 0.71 \\
\hline $\mathrm{PH}_{5}$ & 114 & 115 & 11.19 & 12.35 & 131 & 136 & 10.29 & 11.29 & 0.71 & 0.77 \\
\hline $\mathrm{PH}_{10}$ & 122 & 124 & 12.65 & 13.66 & 140 & 146 & 10.81 & 12.11 & 0.82 & 0.85 \\
\hline SEm \pm & 0.98 & 0.99 & 0.10 & 0.11 & 0.76 & 0.78 & 0.12 & 0.13 & 0.01 & 0.01 \\
\hline $\operatorname{LSD}(p=0.05)$ & 2.86 & 2.90 & 0.29 & 0.31 & 2.21 & 2.29 & 0.35 & 0.39 & 0.032 & 0.034 \\
\hline \multicolumn{11}{|c|}{ Factor III Zinc sulphate $\left(\mathrm{mg} \mathrm{kg}^{-1}\right)$} \\
\hline $\mathrm{Zn}_{0}$ & 111 & 112 & 10.94 & 12.02 & 128 & 133 & 10.14 & 11.18 & 0.61 & 0.65 \\
\hline $\mathrm{Zn}_{12.5}$ & 115 & 117 & 11.69 & 12.69 & 133 & 138 & 10.51 & 11.71 & 0.86 & 0.91 \\
\hline SEm \pm & 0.80 & 0.81 & 0.08 & 0.09 & 0.62 & 0.64 & 0.10 & 0.11 & 0.01 & 0.01 \\
\hline $\operatorname{LSD}(p=0.05)$ & 2.34 & 2.37 & 0.23 & 0.26 & 1.80 & 1.87 & 0.28 & 0.32 & 0.026 & 0.028 \\
\hline \multicolumn{11}{|l|}{ Interaction } \\
\hline $\mathrm{PH} \times \mathrm{NPK}$ & S & $S$ & $\mathrm{~S}$ & $\mathrm{~s}$ & S & $S$ & S & S & S & $\mathrm{S}$ \\
\hline
\end{tabular}

NPK (60-30-30 mg kg-1 corresponding to 120,60 , and $60 \mathrm{~kg} \mathrm{ha}^{-1}$ of $\mathrm{N}, \mathrm{P}_{2} \mathrm{O}_{5} \& \mathrm{~K}_{2} \mathrm{O}$ respectively); PH: Potassium humate 


\begin{tabular}{|c|c|c|c|c|c|c|c|c|c|c|c|}
\hline \multirow[t]{3}{*}{ NPK (\%) } & \multirow{3}{*}{$\begin{array}{l}\text { Potassium humate } \\
\left(\mathrm{mg} \mathrm{kg}^{-1} \text { soil) }\right.\end{array}$} & \multicolumn{2}{|c|}{ Nitrogen } & \multicolumn{2}{|c|}{ Phosphorous } & \multirow{2}{*}{\multicolumn{2}{|c|}{$\begin{array}{c}\text { Potassium } \\
\mathrm{mg} \mathrm{kg}^{-1} \\
\end{array}$}} & \multirow{2}{*}{\multicolumn{2}{|c|}{ Sulphur }} & \multicolumn{2}{|c|}{ Zinc } \\
\hline & & & & & & & & & & & \\
\hline & & 2009 & 2010 & 2009 & 2010 & 2009 & 2010 & 2009 & 2010 & 2009 & 2010 \\
\hline 75 & 0 & 98 & 98 & 9.72 & 10.60 & 115 & 120 & 9.55 & 10.49 & 0.50 & 0.53 \\
\hline 75 & 5 & 108 & 110 & 10.77 & 11.80 & 123 & 128 & 10.14 & 11.13 & 0.53 & 0.59 \\
\hline 75 & 10 & 119 & 123 & 12.59 & 13.53 & 135 & 143 & 10.23 & 11.45 & 0.75 & 0.78 \\
\hline 100 & 0 & 110 & 111 & 10.49 & 11.51 & 127 & 128 & 10.21 & 11.38 & 0.87 & 0.90 \\
\hline 100 & 5 & 119 & 120 & 11.60 & 12.91 & 139 & 144 & 10.43 & 11.45 & 0.90 & 0.95 \\
\hline 100 & 10 & 124 & 125 & 12.72 & 13.79 & 145 & 149 & 11.40 & 12.77 & 0.88 & 0.93 \\
\hline \multicolumn{2}{|c|}{$\operatorname{LSD}(p=0.05)$} & 4.04 & 4.09 & 0.40 & 0.44 & 3.12 & 3.23 & 0.49 & 0.54 & 0.045 & 0.048 \\
\hline
\end{tabular}

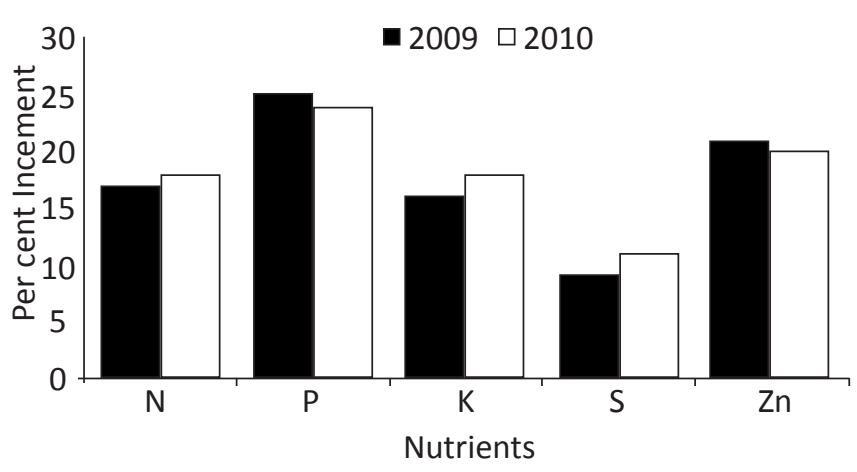

Figure 1: Per cent incement by $\mathrm{PH} 10$ over $\mathrm{PHO}$ of N, P, K, S and Zn in soil durind 2009 and 2010

soil was recorded with $10 \mathrm{mg} \mathrm{kg}^{-1} \mathrm{PH}$ as compared to $\mathrm{PH}_{0}$ and increased $\mathrm{S}$ content by $\sim 9 \%$ over $\mathrm{PH}_{0}$ during first year and $11 \%$ during second year (Table 3 and Figure 1). Same results were also reported by Chenghua et al., 2005; Du ZhenYu et al., 2013; Masciandaro and Ceccanti, 1999.

The application of $10 \mathrm{mg} \mathrm{kg}^{-1} \mathrm{PH}\left(\mathrm{PH}_{10}\right)$ significantly $(p<0.05)$ enhanced the DTPA extractable $\mathrm{Zn}$ content in soil over $\mathrm{PH}_{5}$ and $\mathrm{PH}_{0}$. The per cent increments of DTPA extractable zinc by $\mathrm{PH}_{10}$ over $\mathrm{PH}_{0}$ were 21 during first year and 20 in second years (Figure 1). Interaction effect of PH with NPK and PH with zinc was found to be significant (Table 4) Zinc humic compounds are highly effective in increasing plant-available concentration of $\mathrm{Zn}$ in soils and promote plant growth under zinc deficient soil (Sharif et al., 2002; Garcia et al., 2004).

\section{Conclusion}

There was an enrichment of available N, P, K and $\mathrm{Zn}$ in the soil supplemented with mineral fertilization, $\mathrm{PH}$ and $\mathrm{Zn}$-sulphate. $\mathrm{PH}$ also increased soil fertility indicators such as the BD, WHC and the CEC and had significantly influenced soil physical properties. Application of $10 \mathrm{mg} \mathrm{kg}^{-1} \mathrm{PH}$ along with $100 \% \mathrm{RDF}$ and $12.5 \mathrm{mg} \mathrm{kg}^{-1}$ zinc sulphate caused significant increase $\mathrm{N}$, P, K, S and Zn content in soil as compared to $100 \%$ and $75 \%$ NPK alone.

\section{References}

Ali, A.S., Mohd, K.Y., Hussin, A., Othman, R., Ahmed, O.H., 2010. Impact of potassium humate on selected chemical properties of an acidic soil. Proceedings of the $19^{\text {th }}$ World Congress of Soil Science, Soil solutions for a changing world, Brisbane, Australia, 1-6 th $^{\text {th }}$ August, 2010.

Alvarez-puebla, R.A., Goulet P.J.G., Garrido, J.J., 2005. Characterizationof the porous structure of different humic fractions. Colloids Surface 256, 129-135.

Anonymous, 2015. Agricultural statistics at a glance, Directorate of economics and statistics, Department of Agriculture, Cooperation and farmers welfare, Ministry of Agriculture and farmers welfare, Government of India.

Arjumend, Tuba., Kaleem, M.A., Rafique, E., 2015. Effects of lignite-derived humic acid on some selected soil properties, growth and nutrient uptake of Wheat (Triticum aestivum L.) grown under greenhouse conditions. Pakistan Journal of Botany 47(6), 2231-2238.

Bai, W., Zhang, H., Liu, B., Wu, Y., Song, J., 2010. Effects of super-absorbent polymers on the physical and chemical properties of soil following different wetting and drying cycles. Soil use management 26, 253-260.

Bama, K.S., Selvakumari, G., Santhi, R., Singaram P., 2003. Effect of humic acid on nutrient release pattern in an Alfisol (TypicHaplustalf). Madras Agriculture Journal 90, (10-12), 665-670.

Canellas, L.P., Silva, S.F., Olk, D., Olivares, F.L., 2015. Foliar application of Herbaspirillum seropedicae and humic acid increase maize yields. Journal of Food Agriculture and Environment 13, 146-153.

Charest, M.H., Beauchamp, C.J., Antoun, H., 2004. Effects of the humic substances of de-inking paper sludge on the antagonism between two compost bacteria and Pythium ultimum, FEMS 52, 219-227.

Chenghua, L., Lei, L., Liyu, D., 2005. Effect of humic acids on fixation and release of potassium in cultivated brown soil. Acta Pedologica Sinica 42(3), 472-477.

Chesnin, L., Yien, C.H., 1951. Turbidimetric determination of available sulphate in soils. Soil Science Society of America 
Proceedings 15, 149-151.

Du ZhenYu, Wang QingHua, Liu FangChun, Ma HaiLin, Ma BingYao, Malhi, S.S., 2013. Movement of phosphorus in a calcareous soil as affected by humic acid. Pedosphere 23(2), 229-235.

Garcia-Mina, J, M., Antolin, M.C., Sanchez-Diaz, M., 2004. Metal-humic complexes and plant micronutrient uptake: A study based on different plant species cultivated in diverse soil types. Plant and Soil 258, 57-68.

Guo, J.H., Liu, X.J., Zhang, Y., Shen, J.L., Han, W.X., Zhang, W.F., Christie, P., Goulding, K.W.T., Vitousek, P.M., Zhang, F.S., 2010. Significant acidification in major Chinese croplands. Sciences 327, 1008-1010.

Ibrahim, E.A., Ramadan, W.A., 2015. Effect of zinc foliar spray alone and combinedwithhumic acid or/and chitosan on growth, nutrient elements content andyield of dry bean (Phaseolus vulgaris L.) plants sown at different dates. Scientia Horticulturae 184, 101-105.

Jackson, M.L., 1973. Soil Chemical Analysis.Prentice Hall of India Pvt Ltd. New Delhi.

Kumar, D., Singh, A.P., Raha, P., Rakshit, A., P. Kishor, Singh, C.M., 2013. Potassium Humate: A Potential soil conditioner and plant growth promoter. International Journal of Agricultural Environment and Biotechnology 6 (3), 441-446.

Kutuk, C., Caycy, G., Baran, A., Baskan, O., 2000. Effect of humic acid on some soil properties. In: International Symposium on Desertification. Soil Science Society of Turkey, Konya, Turkey.

Lim, S.L., Wu, T.Y., Lim, P.N., Shak. K.P.Y., 2015. The use of vermicompost in organic farming: overview, effects on soil and economics. Journal of Science and Food Agriculturer 95, 1143-1156.

Lindsay, W.L., Norvell, W.A., 1978. Development of DTPA soil tests for Fe, Mn, $\mathrm{Zn}$ and $\mathrm{Cu}$. Soil Science Society of America journal 42, 421-428.

Masciandaro, G., Ceccanti, B., 1999. Assessing soil quality in different agro-ecosystems through biochemical and chemicostructural properties of humic substances. Soil and Tillage Research 51, 129-137.

Naidu, Y., Meon, S., Siddiqui, Y., 2013. Foliar application of microbial-enrichedcompost tea enhances growth, yield and quality of muskmelon (Cucumis melo L.) cultivated under fertigation system. Scientia Horticulturae 159, 33-40.

Olivares, F.L., Aguiar, N.O., Rosa, R.C.C., Canellas, L.P., 2015. Substratebiofortification in combination with foliar sprays of plant growth promotingbacteria and humic substances boosts production of organic tomatoes. Scientia Horticulturae 183, 100-108.
Olsen, S.R., Cole, C.V., Watanabe, F.S., Dean, L.A., 1954. Estimation of available phosphorus in soils by extraction with sodium bicarbonate, USDA, Circular 939.United State Department of Agriculture USA.

Richards, L. A., 1954. Diagnosis and improvement of saline and alkali soils.USDA Agriculture Handbook 60. Washington, D.C.

Sarwar, M., Akhtar E.M., Hyder, S.I., 2012. Effect of humic acid and phosphorus on yield, nutrient availability in soil and uptake by peas._Prime Journal of Physical Science $1(5), 53-57$.

Schollenberger, C.J., Simon, R.H., 1945. Determination of exchange capacity and exchangeable bases in soilammonium acetate method. Soil Science 59, 13-24.

Shahid, S.A., Qidwai, A.A., Anwar, F., Ullah, I., Rashid, U., 2012. Effects of a Novel Poly (AA-co-AAm)/AIZnFe $\mathrm{O}_{4} /$ potassium humate superabsorbent hydrogel nanocomposite on water retention of sandy loam soil and wheat seedling growth. Molecules 17, 12587-12602.

Sharif, M., Khattak, R.A., Sarir, M.S., 2002. Effect of different levels of lignitic coal derived humic acid on growth of maize plants. Communications in Soil Science and Plant Analysis 33, 3567-3580.

Singh, S.N., Verma, A., 2007. The potential of nitrification inhibitors to manage the pollutioneffect of nitrogen fertilizers in agricultural and other soils. Environmental Practice 9, 266-279.

Subbiah, B.V., Asija, G.L., 1956. A rapid procedure for the determination of available nitrogen in soils Current Science 25, 259-260.

Suh, H.Y., Yoo, K.S., Suh, S.G., 2014. Tuber growth and quality of potato (Solanum tuberosum L.) as affected by foliar or soil application of fulvic and humic acids. Horticulture, Environment, and Biotechnology 55, 183-189.

Triplett, G.B. Jr., Van Doren, D.M., Schmidt, B.L., 1968. Effect of corn (Zea mays L.) stove mulch on no-tillage corn yield and water infiltration. Agronomy Journal 60, 236-239.

Turgay, O.C., Karaca, A., Unver, S.,Tamer N., 2011. Effects of coal- derived humic substance on some soil properties and bread wheat yield. Communications in Soil Science and Plant Analysis 42, 1050-1070.

Vallini, G., Pera, A., Avio, L., Valdrighi, M., Giovannetti, M., 1993. Influence of humic acids on laurel growth, associated rhizospheric microorganisms, and mycorrhizal fungi. Biology and. Fertility of Soils 16, 1-4.

Walkley, A., Black, C.A., 1934. An examination for Degtjareff method for determining soil organic matter and a proposed modification of the chromic acid titration method. Soil Science 34, 29-38. 